\title{
Multinational Corporations: Myths and Realities
}

\section{Mohammad Saif Ahmad*}

Western Institute of Technology, Melbourne, Australia

*Corresponding author: Mohammad Saif Ahmad, Trainer and Assessor, Western Institute of Technology, Melbourne, Australia, Tel: +61 3 9017 5033; E-mail: msaifahmad@gmail.com

Received date: July 23, 2014; Accepted date: August 14, 2014; Published date: August 24, 2014

Copyright: ( 2014 Ahmad MS. This is an open-access article distributed under the terms of the Creative Commons Attribution License, which permits unrestricted use, distribution, and reproduction in any medium, provided the original author and source are credited

\begin{abstract}
The $17^{\text {th }}$ and $18^{\text {th }}$ centuries gave birth to a number of multinational trading companies that played crucial role in the commercial and industrial development of Asia, Latin America and Africa. In the Post-World War II era, establishment of International Monetary Fund, World Bank and General Agreement on Tariffs and Trade gave further flip to global trade and led to more closely linked world markets. During the last five decades or so the MNCs have grown so much in power and visibility that they have come to be viewed with increasing suspicion both by national and international entities. Despite their unquestionable contributions, certain abuses have occurred in the process. Continuously worrying concern is that the current MNC-led globalization has been emphasizing economic integration while justice, mutual help and cooperation - pre-requisites for integrating mankind - are being ignored.
\end{abstract}

\section{Keywords: GATT; MNC; Globalization; IMF; WTO; LPG}

\section{Introduction}

International trade has been in existence since the beginning of the sixteenth century [1]. It acquired modern form in $17^{\text {th }}$ and $18^{\text {th }}$ centuries with the creation of large European based monopolistic concerns. At that time they were considered as symbols of civilization and played a pivotal role in the commercial and industrial development of Asia, Latin America and Africa. By the end of $19^{\text {th }}$ century, development of cheaper and faster modes of transport, continuous improvements in communication technology gave further flip to global trade and led to more closely linked world markets. In the post-world war II era, establishment of International Monetary Fund (IMF), World Bank and General Agreement on Tariffs and Trade (GATT), advances in shipping technology (containerization) resulted in cheaper handling of goods.

According to International Labor Organization (ILO) multinational enterprises include enterprises, whether they are public, mixed or private ownership, which own or control production, distribution, services or other facilities outside the country in which they are based. The three multinational entities mentioned above had been trying, right from their inception, for ever increasing global trade. The Uruguay Round of GATT that ultimately led to the establishment of World Trade Organization is, so far, the most important as far as the multinational corporations are concerned. Though the MNCs had been progressing from the very beginning but not as fast as during 1980s. In fact, this period of the last century saw changes of such far reaching consequences that nobody could have dreamt of. The dismemberment of the erstwhile USSR and demolition of Berlin Wall resulting in re-unification of East and West Germany are only two examples. Overnight, around fifty countries switched over from socialist to capitalist system and thereupon the process of Liberalization, Privatization and Globalization (LPG) set in. The postLPG period has seen tremendous progress for the multinational companies because of the removal of most of the trade restrictions accompanied by elimination of capital exchange controls by the developing nations. Consequently, during the last five decades or so MNCs have grown in power and visibility and have come to be viewed with increasing suspicion by the national government agencies, international trade and labor organizations. As global trade barriers continue to be removed, MNCs continue to expand their power and influence. Except for the industrialized capitalist countries of the West and about a dozen newly industrialized nations, they are considered utilitarian enterprises with little or no concern for the social or economic well-being of the countries in which they operate.

The top MNCs are headquartered in the USA, Western Europe, and Japan and they have the capacity to influence or shape international trade, production and financial transactions. WTO, IMF and the World Bank are the three global institutions that write the basic rules and regulations of economic, monetary and trade relations between countries. It should, however, be noted that the developing nations have loosened their trade rules under pressure from the IMF and Word Bank. They have underdeveloped domestic markets and do not have appropriate laws in place to enable national financial institutions to withstand foreign competition. Since their administrative set up, judicial system and law-enforcing agencies cannot guarantee the social discipline and political stability that are necessary to support growthfriendly atmosphere, the MNCs have been heavily investing in the countries of their choice - generally high-income countries and a few Southeast Asian countries and Latin America.

\section{MNCs and the New Markets}

When a company makes the commitment to go international, it has to choose an entry strategy. The company's decision must reflect an analysis of its capabilities, market potential, degree of marketing involvement, availability of financial resources and the commitment its management is prepared to make. The strategy of foreign marketing may range from infrequent and indirect exporting, with minimum investment, to capture and maintain specific share of global markets requiring huge investment. Indirect exporting usually means that the manufacturer sells its products to large retailers like Wal-Mart or Sears, wholesale supply houses and trading companies in the home 
Page 2 of 3

market who, in turn, will export the products to customers abroad. The variety of ways in which the MNCs can and do enter into new markets are licensing and franchising, merger and acquisitions, sequential market entry and joint ventures.

\section{Licensing and Franchising}

The small and medium sized entities (SMEs) use licensing for establishing a foothold in overseas markets without involving huge capital investments. In licensing, the licensor permits a firm in a foreign country to use its patents, copyrights, trademarks, technology, marketing skills, technical know-how etc. in return for royalty payments. Because of scarcity of financial resources and various restrictions that forbid other means of entering into the foreign market, the SMEs adopt this strategy. Here, the licensee usually becomes the licensor's competitor after the expiry of licensing agreement. Continuous innovation can pre-empt any such potential or actual competition. In franchising, the parent company (franchiser) grants another company in a foreign country the right to do business in a specific manner. It may take the form of selling the franchiser's products or using franchiser's name in production, distribution and marketing techniques.

\section{Mergers and Acquisitions}

Merger or direct acquisition of existing companies in the new markets is the most straightforward method of penetration. This method is also known as foreign direct investment that enables the MNCs to take full advantage of the economies of scale that it provides. The rush of mergers and acquisitions during the late 1990s of the last century within the global automotive industries is illustrative of this method of gaining access to new markets. Of course, it was boosted by increased global competition.

In merger, two companies come together but only one of them survives while the other goes out of existence. In acquisition, the acquirer gets control over the acquired company. It is done through mutual consent and willingness of both the companies. The intention behind acquisition is to acquire new technology and reduce competition that provides quick access to global marketing and distribution network. The acquisition of the second largest global tea marketer Tetley by Tata Tea, acquisition of Indian rights for three anti-infective brands from the US pharmaceutical firm EliLily by Nicholas Piramal, and acquisition of global coats Viyella brands like Louis Phillipe, Allen Solly, and Peter England by Indian Rayon are examples of acquisitions.

The MNCs also enter into new markets through sequential market entry. It also often involves foreign direct investment in the form of setting up or acquiring of concerns operating in new markets related to the MNCs product line, Japan's Sony Corporation made sequential entry into the USA in 1972 by setting up a small television assembly plant in San Diego, California. It continued to expand and diversify its operations in the USA. Then it started producing semi- conductors and personal communications products. Thus, a multinational can use its core product line to defeat indigenous competition and expand sequential corporate activities over a period of time.

\section{Joint Ventures}

The less risky way for companies to enter into foreign markets that pose legal and cultural barriers is through joint venture. It avoids political and commercial risks attached to acquisition of an existing company. Joint Ventures may be contractual or equity based. In contractual joint ventures, two or more companies share certain assets and liabilities for a specific purpose or time. Such types of joint ventures are very common in consultancy services, construction projects and extractive industries.

In equity-based joint ventures, a multinational corporation or even a foreign government and a domestic company hold shares in the subsidiary company and share profits in proportion to their capital contributions. The advantage of such a joint venture for the multinational company is that it can minimize its risks by spreading investments across many locations.

This has particularly been the case of countries under direct communist regimes or the countries practicing communist philosophy under different democratic labels (India being one of them). In such ventures, the venture partners of the new markets retained considerable or even complete autonomy and simultaneously enjoyed the benefits of technology transfer and management and production expertise from the MNCs. Such joint ventures proved very awkward in the long run as the MNCs found the venture partners as their formidable competitors and many of them had to attempt more direct new market penetration.

\section{Concerns about MNCs}

While success and pervasiveness of the MNCs has been unquestionable, their motives and actions have been called into question by a number of labor organizations, government agencies, environmental protection and social welfare organizations all over the world. National and international labor unions have expressed concern that MNCs of industrialized nations generally avoid labor negotiations by simply moving their jobs to other developing countries where wage rates are markedly low. National labor unions are usually obliged to negotiate with national subsidiary of a multinational company in their country, which is usually willing to negotiate contract terms only on the basis of domestic wage standards, which may be well below those in the parent company's country. But lower labor cost is not the only factor for MNCs and their affiliates to determine the location of their business and service operations; other factors such as political stability, education levels, infrastructure facilities, taxes, future market potential and governmental regulations are more decisive.

Outsourcing and insourcing are other problem areas of the MNCs. They are autonyms. Offshore outsourcing or off shoring is the practice of using cheap overseas labor to manufacture goods or provide services only to sell them back in home markets. Many Americans are presently concerned about the issue of whether US multinational companies will continue to export jobs to cheap foreign labor markets. They claim that it takes jobs from Americans and causes trade imbalance. When non-US companies set up business operations in USA, they sell the goods manufactured in the USA to American consumers. But when US companies outsource jobs to cheap foreign labor markets, they also sell the goods produced by them to Americans, rather than to the consumers of the country in which they are produced. Due to this, many states in America have passed legislations aimed at limiting off shoring, state aid and tax breaks to companies that practice off shore outsourcing.

Insourcing is the practice of non-US multinational companies employing US workers. Foreign multinational automakers are the 
Page 3 of 3

largest in sources. They have set up plants in USA, thus ensuring access to American consumers. Toyota, for example, now makes more than one-third of its profits from US car sales.

The multinational companies also face genuine problems when they take their business operations to developing countries. They generally suffer from poor governance, unemployment, widespread poverty [2], weak infrastructure, health care problems, very skewed income distribution, illiteracy and above all widespread corruption. The reality is that multinationals seek to maximize profits and efficiency on a world wide basis; their ultimate objective is not the economic wellbeing of a particular country but the success of their global operations. For many of the weaknesses mentioned above, the national governments of developing world are to blame and not the MNCs. They should first put their houses in order before unnecessarily blaming the multinational companies. So, under the prevailing circumstances, the host countries should not and, of course, cannot try to dictate their terms to the MNCs [3].

Sometimes, multinational companies do take undue advantage of their dominating position under the present MNC-led globalization. The former German Chancellor Gerhard Schroeder [4] was right when he remarked, 'The tasks we are facing require a strong multilateral system based on the rule of law rather than on the idea of the survival of the fittest'. The point that needs to be emphasized is that economic, social and political integration is not going to integrate the mankind, unless it is accompanied by justice, mutual help and cooperation. A similar remark by the Noble Peace Prize winner Nelson Mandela [5] is also worth noting. He said, 'It worries me that our world is becoming a global village only for the exchange of goods and information - not as a place of shelter, livelihood, security and dignity for all who live in it.' While economic integration is being emphasized, justice is being ignored. Justice demands that as the production capacity, trade and exports of the industrial nations increase, the developing nations should also experience such increases.

Environmental protection agencies often claim that the MNCs undertake environmentally hazardous operations in countries with minimal environmental legislations [6]. Government agencies fear the growing pervasiveness, power and influence of the multinational companies that can be used as a threat of removing their business operations from their country in order to secure favorable regulations and legislation. Welfare organizations express concern that the MNCs are not as much interested in social matters as they should have been in countries in which they maintain their subsidiary operations.

Undoubtedly, all aforementioned concerns are valid and abuses have occurred. Abuse of sweatshop labor by Nike, outcry against operations of Shell Oil Company in Nigeria and Pepsi Company in Burma (Myanmar), explosion of an unsafe chemical plant of Union Carbide in Bhopal (India) resulting in loss of life of thousands of people in surrounding areas and environmental catastrophe caused by Prince William Sound in Alaska are the examples widely quoted in international media that led to ceaseless bad publicity against multinational companies involved. It continues to serve as reminder of the long term costs borne by such companies for ignoring environmental protection and labor welfare and safety standards. But growing consumer awareness of environment and social issues, constraints of moving their operations into areas with excessively low wage rates given the lack of availability of skilled labor in such areas, general awareness of global issues due to widespread growth in educational facilities, monitoring of activities of MNCs by the international conventions of governments without fear of economic reprisal, stop multinational companies from wielding unlimited power over even their own business operations. The happy sign is that the trend has been continuing [7].

\section{Conclusion}

The MNCs operate at the crossing point between production, international trade and foreign investments. Despite a number of challenges faced by the MNCs, they help in strengthening domestic competition resulting in quality goods/services at lower costs being provided to the consumers. Consumers cover all sections of the society. In developing countries, big MNCs can use and do use, to some extent, their economies of scale to push local firms out of business. But the consumers are ultimately benefited. We do agree that opponents of MNCs are not totally wrong. But they must realize that it is the MNCs alone that provided India with heavy engineering goods, life-saving drugs, medical diagnostic equipments, information technologies, electronic gadgets, rubber products, aircrafts, chemicals and what not. Had our own enterprises been efficient, productive and innovative, we would not have imported shirts, jeans and electronic gadgets. India could produce them all at much cheaper rates. Under the present globalized regime of which India itself is part, we must allow MNCs to operate in all those areas in which we lack the expertise. We should not view them as saboteurs; we should import technologies through them and emulate their standards in letter and spirit.

\section{References}

1. Dunning JN (2003) International Trade: New Patterns of Trade, Production and Investment, Routledge, London.

2. Mohammad N (2005) Economic Liberalization and Poverty in Developing Countries. Journal of Contemporary Asia, p. 109.

3. Prahlad CK, Kenneth L (1998) The End of Corporate Imperialism, Harvard Business Review.

4. Schroeder G (2006) Wanted a Stronger UN, India Today, INDIA.

5. Mandela N (2006) Human Will is the Key, India Today, India.

6. The Economist (2005) Time to Bring it Back Home?, p.63.

7. Zhao L (1998) Labour Management Bargaining and Transfer Pricing in Multinational Corporations, Canadian Journal of Economics. 